\title{
Bezerromycetales and Wiesneriomycetales ord. nov. (class Dothideomycetes), with two novel genera to accommodate endophytic fungi from Brazilian cactus
}

\author{
Jadson D. P. Bezerra ${ }^{1,2},{ }^{*}$, Rafael J. V. Oliveira ${ }^{1,2}$, Laura M. Paiva ${ }^{1}$, Gladstone A. Silva ${ }^{1,2}$, \\ Johannes Z. Groenewald ${ }^{3}$, Pedro W. Crous ${ }^{3,4,5}$, Cristina M. Souza-Motta ${ }^{1,2}$ \\ 1. Departamento de Micologia Prof. Chaves Batista, Universidade Federal de Pernambuco, Av. Prof. Moraes \\ Rego, s/n, Centro de Biociências, Cidade Universitária, CEP: 50670-901 Recife, PE, Brazil \\ 2. Programa de Pós-Graduação em Biologia de Fungos (PPG-BF), Departamento de Micologia Prof. Chaves \\ Batista, Universidade Federal de Pernambuco, Av. Prof. Moraes Rego, s/n, Centro de Biociências, Cidade \\ Universitária, CEP: 50670-901 Recife, PE, Brazil \\ ${ }^{3 .}$ CBS-KNAW Fungal Biodiversity Centre, Uppsalalaan 8, 3584 CT Utrecht, The Netherlands \\ 4. Department of Microbiology and Plant Pathology, Forestry and Agricultural Biotechnology Institute (FABI), \\ University of Pretoria, P. Bag X20, Pretoria 0028, South Africa \\ 5. Microbiology, Department of Biology, Utrecht University, Padualaan 8, $3584 \mathrm{CH}$ Utrecht, The Netherlands \\ *Correspondence to: Jadson D. P. Bezerra, jadsondpb@gmail.com
}

\begin{abstract}
During a survey of endophytic fungi from the cactus Tacinga inamoena in a Brazilian tropical dry forest (Caatinga) some undescribed ascomycetous fungi were isolated. These fungi are characterized by superficial and immersed, globose to subglobose, smooth or hairy ascomata, bitunicate asci, and muriformly septate, ellipsoidal ascospores. Multigene phylogenetic analyses using sequences from partial ITS, SSU and LSU nrDNA and the translation elongation factor 1-alpha gene (tef1) demonstrated a monophyletic clade accommodating these endophytic fungi in the class Dothideomycetes, closely related to the order Tubeufiales. Based on morphological features and phylogenetic analyses, these fungi could not be placed in the order Tubeufiales, in the new order Wiesneriomycetales, or any other known genus in the class Dothideomycetes. Thus, two new genera (Bezerromyces, with B. brasiliensis and B. pernambucoensis, and Xiliomyces with $X$. brasiliensis), a new family (Bezerromycetaceae) and a new order (Bezerromycetales) are introduced to accommodate these novel taxa. Our phylogenetic analyses also demonstrated that the clade accommodating Wiesneriomycetaceae represents a new order, here introduced as Wiesneriomycetales.
\end{abstract}

Keywords: Endophytes, Fungal diversity, Multigene phylogeny, Tacinga inamoena, Taxonomy 


\section{Introduction}

Endophytes are enigmatic microorganisms that live in tissues of all plants without appearing to cause damage. These microorganisms can help their hosts by protecting them against temperature, stresses caused by drought and humidity, UV light, herbivores, and plant pathogenic organisms (Redman et al. 2002; Hubbard et al. 2014; Jia et al. 2016). Endophytes can stimulate the growth of plants via the production of phytohormones, promoting the germination and dispersal of seeds, and the biocontrol of pathogens (Porras-Alfaro and Bayman 2011; Vidal and Jaber 2015). These microorganisms can also be utilized for their biotechnological potential in the production of secondary metabolites, phytoremediation, and in the degradation of environmental pollution (Wang and Dai 2011; Chandra 2012; Santos et al. 2015). In addition to all environmental and biotechnological benefits, these microorganisms are extremely important for the estimation of fungal diversity. Several studies of endophytic fungi have contributed directly to the discovery of new fungi, their ecology, host-fungus relationships, and their distribution in different agricultural crops and natural environments. Studies on endophytic fungi have been conducted in a range of climatic and ecological zones, including temperate and tropical forests, polar regions, deserts, arid and semiarid environments (Arnold et al. 2000; Murali et al. 2007; Rosa et al. 2009; Sun et al. 2012; Bezerra et al. 2013, 2015; Nascimento et al. 2015; Massimo et al. 2015).

One of the most important Brazilian tropical dry forests is called "Caatinga". This ecosystem is exclusive to Brazil, covers most states in the northeastern region of the country, and includes numerous plant species belonging to about 123 different families (Flora do Brasil 2020, http://floradobrasil.jbrj.gov.br/). Despite the fact that the Caatinga harbours several endemic species, including plants, birds, mammals and fishes, little attention has been paid to its conservation, considering the diverse biota and striking landscape, which results in an underestimation of Brazilian biodiversity (Bernard et al. 2014). According to information from the Caatinga Association (http://www.acaatinga.org.br/), only about $8 \%$ of the Caatinga ecosystem is presently protected. This ecosystem maintains 90 species of Cactaceae plants, with some being rare and endemic. These species require attention due to the fact that they appeared on the Convention on International Trade in Endangered Species of Wild Fauna and Flora list, underlining the importance of these cacti in the international wildlife trade (Cabral et al. 2013; Meiado et al. 2015; Taylor et al. 2015). Studies on fungal diversity in the Caatinga published to date have revealed many known and unknown taxa belonging to Ascomycota, Basidiomycota and Mucoromycotina (Maia et al. 2015). The study of the endophytic fungal community from plants of the Caatinga is still incipient, and very few reports have been published on fungal endophytes from cacti growing in this environment (Bezerra et al. 2012, 2013; Freire et al. 2015).

The first study of endophytic fungi from the cactus Opuntia stricta was published by Fisher et al. (1994) in Australia. They reported endophytic fungi belonging to 13 families and 8 orders. Similar results were obtained by Suryanarayanan et al. (2005), who studied 21 cacti species in the USA and reported the isolation of endophytes belonging to 8 families and 6 orders. Recently, Silva-Hughes et al. (2015) used a medicinal cactus O. humifusa in the USA to estimate the endophyte diversity and their antifungal activity. Using phylogenetic analyses they grouped the endophytes in 17 taxa representing 9 families and 6 orders. A 
similar study on the diversity of the two native and sympatric cacti, Myrtillocactus geometrizans and $O$. robusta in Mexico, was recently published by Fonseca-García et al. (2016). Although they used molecular technics to estimate the endophytic fungal diversity, several operational taxonomic units (OTUs) were identified only as Ascomycota and others were identified as fungi belonging to 14 different orders.

In Brazil, only three studies of endophytes from cacti growing in the Caatinga have thus far been conducted. The first, published by Bezerra et al. (2012), studied the cactus $O$. ficusindica and the capacity of these endophytic fungi to produce hydrolytic enzymes. The authors identified 12 genera belonging to 8 families of 7 orders. Bezerra et al. (2013) studied the cactus Cereus jamacaru subsp. jamacaru and reported endophytic fungi belonging to 30 genera in 14 families of 10 orders in Ascomycota, 2 families of 3 orders in Basiodiomycota, and 2 families of 1 order in Mucoromycotina. Freire et al. (2015) studied the influence of an insect (Hemiptera) on the endophytic fungal community of $O$. ficus-indica, and observed endophytes belonging to 9 families of 7 orders. These few reports on fungal endophyte diversity from cacti species revealed a great diversity of unknown fungi, which could greatly contribute to the global estimates of fungal microdiversity.

During a recent survey of endophytic fungi associated with the cactus Tacinga inamoena from the Caatinga, four strains were obtained. These strains did not fit morphologically into any currently known genus. Therefore, we carried out DNA sequence analyses of four loci (ITS, SSU, LSU, and tef1) to determine the phylogenetic position of these strains and to resolve their taxonomic status.

\section{Materials and methods}

\section{Isolation of endophytic fungi from cactus}

Endophytic fungi were isolated as described by Bezerra et al. (2013) from the cactus Tacinga inamoena (K. Schum.) N.P. Taylor \& Stuppy growing in Brazilian tropical dry forest (Caatinga), Catimbau National Park, Buíque municipality, Pernambuco state, Brazil $\left(8^{\circ} 36^{\prime} 35^{\prime \prime} \mathrm{S}, 37^{\circ} 14^{\prime} 40^{\circ} \mathrm{W}\right)$, and the Sustainable family farming plots, Itaíba municipality, Pernambuco state, Brazil $\left(9^{\circ} 08.895 \mathrm{~S}, 37^{\circ} 12.069 \mathrm{~W}\right)$. The collections were authorized by the Ministério do Meio Ambiente (MMA)/Instituto Chico Mendes de Conservação da Biodiversidade (ICMBio); permission number: 40331-1/authentication code 87451826 issued on 4 November, 2013.

\section{Morphology}

Endophytic fungi isolated from the cactus were cultured on malt extract agar (MEA), potato dextrose agar (PDA), water agar (WA), and synthetic nutrient deficient agar (SNA) (Crous et al. 2009), and incubated at $22^{\circ} \mathrm{C}$ under a natural day-night cycle. Macro- and micromorphological analyses (colony diameter, texture, pigmentation, margin appearance, exudates, and colours) were performed after 2 weeks, and the structures of reproduction were visualized after 2-3 months on WA and SNA culture media. Slide preparations were mounted in clear lactic acid. Endophytic strains are deposited in the culture collections of Micoteca URM Profa. Maria Auxiliadora Cavalcanti (Federal University of Pernambuco, 
Recife, Brazil - www.ufpe.br/micoteca, WCDM 604) and the CBS-KNAW Fungal Biodiversity Centre (CBS), Utrecht, The Netherlands (under Material Transfer Agreement - MTA No. 05/2015/Micoteca URM, issued on 14 April, 2015). Herbarium materials are deposited in Herbário URM Pe. Camilo Torrend (Federal University of Pernambuco, Recife, Brazil http://inct.florabrasil.net/participantes/herbarios-curadores/urm/) and the CBS-KNAW Fungal Biodiversity Centre (CBS). Nomenclature and taxonomic information were deposited in MycoBank (www.mycobank.org) (Crous et al. 2004).

\section{DNA extraction, amplification (PCR) and sequencing}

Genomic DNA extraction was performed using the Wizard ${ }^{\circledR}$ Genomic DNA Purification Kit (Promega, USA) according to the manufacturer's instructions. The primers NS1/NS4 (White et al. 1990), LROR/LR5 (Vilgalys and Hester 1990), EF3Fd (Groenewald et al. 2013)/EF12218R (designed by S. Rehner - www.aftol.org/pdfs/EF1primer.pdf) and ITS5/ITS4 (White et al. 1990) were used to amplify part of the nuclear ribosomal small subunit (SSU) of the rDNA, part of the nuclear ribosomal large subunit (LSU) of the rDNA, part of the translation elongation factor 1-alpha (tef1), and the ITS region (first and second internal transcribed spacer regions and intervening 5.8S nrDNA), respectively. The ITS sequences were not included in the phylogenetic analyses.

Amplification reactions, with a total volume of $12.5 \mu \mathrm{L}$, were composed of $1 \times$ PCR buffer (Bioline, Luckenwalde, Germany), 5.6\% dimethyl sulfoxide (DMSO) (v/v), $20 \mu \mathrm{M}$ dNTPs, $0.2 \mu \mathrm{M}$ of each forward and reverse primers, $0.25 \mathrm{U}$ of Taq DNA polymerase (Bioline), and 10 ng of genomic DNA. The PCR conditions were: start step of 5 min at $94{ }^{\circ} \mathrm{C}$, followed by 35 cycles of $30 \mathrm{~s}$ at $94{ }^{\circ} \mathrm{C}, 50 \mathrm{~s}$ annealing (at $48^{\circ} \mathrm{C}$ for SSU, LSU and ITS, and at $54{ }^{\circ} \mathrm{C}$ for tef1), and $1 \mathrm{~min}$ and $30 \mathrm{~s}$ extension at $72{ }^{\circ} \mathrm{C}$, followed by a final extension step of 7 min at $72{ }^{\circ} \mathrm{C}$ and a cool-down step to $10^{\circ} \mathrm{C}$. The PCR amplicons were visualized with GelRed Nucleic Acid Gel Stain (Biotium, CA, USA) during 1\% agarose gel electrophoresis.

Amplicons were sequenced using the same PCR primers sets with a BigDye Terminator Cycle Sequencing Kit v.3.1 (Applied Biosystems, Foster City, CA, USA) according to the manufacturer's instructions. DNA sequencing amplicons were purified through Sephadex G50 Superfine columns (GE Healthcare Life Sciences, Eindhoven, The Netherlands) in MultiScreen HV plates (Merck Millipore, Darmstadt, Germany). Sequences were analysed on an ABI 3730xI DNA Analyzer (ThermoFisher Scientific, The Netherlands). The consensus sequences were computed and visually inspected using SeqMan v.7.0.0 (DNASTAR, Madison, WI, USA) and/or MEGA v.6 software (Tamura et al. 2013).

\section{Phylogenetic analyses}

To infer a preliminary phylogenetic relationship for the new sequences, an initial alignment of the newly generated sequences (SSU, LSU, and tef1) and 217 Dothideomycetes and Eurotiomycetes taxa, extracted from the dataset of Boehm et al. (2015, TreeBASE Study ID S16151) with two species from Lecanoromycetes as outgroup, was performed using the online MAFFT interface (Katoh and Standley 2013; http://mafft.cbrc.jp/alignment/server). This alignment was used to infer a preliminary phylogenetic relationship for the new 
sequences based on Maximum Parsimony (MP) and Maximum Likelihood (ML) analyses (data not shown).

Based on the initial analysis, a second alignment was constructed on a subset from the original to which were added additional sequences from Boonmee et al. (2014), who introduced Tubeufiales as well as selected sequences from Patellariales (Boehm et al. 2015), Pleosporales (Zhang et al. 2009; Wanasinghe et al. 2014; Ariyawansa et al. 2015; Liu et al. 2015), Wiesneriomycetaceae (Suetrong et al. 2014; Pratibha et al. 2015; Santos 2015; Crous et al. 2016) and Valsariales (Zhang et al. 2009; Jaklitsch et al. 2015). In the second alignment, Dendrographa decolorans (DUKE 47570) was used as an outgroup taxon. The phylogenetic analyses were based on MP, ML and Bayesian Inference (BI). PAUP (Phylogenetic Analysis Using Parsimony) v.4.0b10 (Swofford 2003) was used to conduct the MP analyses with 1000 bootstrap replicates. Alignment gaps were treated as missing data. For ML analyses, RAxMLHPC BlackBox (8.2.8) (Stamatakis 2008) was used to do a fast tree search using the GTRGAMMA substitution model and 500 fast bootstrap replicates. The $\mathrm{BI}$ analysis was performed using MrBayes v.3.2.1 (Ronquist et al. 2012). Based on MrModeltest v.2.2 (Nylander 2004) results, the three partitions were analysed using the $G T R+I+G$ model. Support values (ML bootstrap - ML-BS; MP bootstrap - MP-BS; BI posterior probability BPP) were calculated for all analyses and the tree length ( $T L)$, consistency index (Cl), retention index (RI) and the rescaled consistency index (RC) for the MP analysis. The phylogenetic tree was visualized in Geneious v.5.5.7 (Kearse et al. 2012) and the layout of the tree was done in Adobe Illustrator v.CS5.1. The newly obtained sequences were deposited in the NCBI (www.ncbi.nlm.nih.gov; Table 1) and the alignment and phylogenetic tree in TreeBASE (Study ID S19537; www.treebase.org).

Table 1. GenBank accession numbers of type species and/or references strains used in this study. Sequences obtained in this study are shown in bold

Species

Acanthostigma chiangmaiense

Allophaeosphaeria muriformia

Bambusaria bambusae

Bezerromyces brasiliensis

Bezerromyces pernambucoensis

Botryobambusa fusicoccum

Botryosphaeria agaves

Botryosphaeria dothidea

Cophinforma atrovirens

Dematiopleospora mariae

Dendrographa decolorans

Glyphium elatum

Glyphium elatum

Helicangiospora lignicola

Helicoma chiangraiense

Helicoma fagacearum

Hysteropatella clavispora
Collection accession number(s)

MFLUCC 10-0125

MFLUCC 13-0349

CBS 139763

URM 7411 (CBS 141545)

URM 7412 (CBS 141546)

MFLUCC 11-0143

MFLUCC 11-0125

CBS 115476

MFLUCC 11-0425

MFLUCC 13-0612

DUKE 47570

BPI 892669

BPI 892671

MFLUCC 11-0378

MFLUCC 10-0115

MFLUCC 11-0379

CBS 247.34
GenBank accession numbers

LSU SSU TEF1- $\alpha$ ITS

JN865197 JN865185 KF301560 JN865209

KP765681 KP765682 - KP765680

KP687813 KP687962 KP687983 KP687813

KX518623 KX518627 KX518631 KX470390

KX518624 KX518628 KX518632 KX470391

JX646809 JX646826 - NR_111793

JX646808 JX646825 - N NR_111792

DQ678051 DQ677998 DQ767637 KF766151

JX646817 JX646833 - JX646800

KJ749653 KJ749652 KJ749655 KJ749654

AY548815 AY548809 DQ883725 -

KM220934 KM220937 KM220932 KM220943

KM220936 KM220939 KM220933 KM220945

KF301531 KF301539 KF301552 KF301523

JN865188 JN865176 KF301551 JN865200

KF301532 KF301540 KF301553 KF301524

AY541493 DQ678006 DQ677901 - 
Species

Kellermania macrospora

Kellermania yuccigena

Murispora rubicunda

Myrmaecium fulvopruinatum

Myrmaecium rubricosum

Myrmaecium rubrum

Parawiesneriomyces syzygii

Patellaria atrata

Patellaria cf. atrata

Patellaria cf. atrata

Phaeotrichum benjaminii

Phyllosticta ampelicida

Phyllosticta citricarpa

Populocrescentia forlicesenensis

Pseudogliophragma indicum

Saccharata proteae

Speiropsis pedatospora

Trichodelitschia bisporula

Trichodelitschia munkii

Tubeufia chiangmaiensis

Tubeufia javanica

Valsaria insitiva

Valsaria lopadostomoides

Valsaria neotropica

Valsaria robiniae

Valsaria rudis

Valsaria spartii

Wiesneriomyces

conjunctosporus

Wiesneriomyces

conjunctosporus

Wiesneriomyces

conjunctosporus

Wiesneriomyces

conjunctosporus

Xiliomyces brasiliensis

Xiliomyces brasiliensis
Collection accession number(s)

CBS 131716

CBS 131727

IFRD 2017

CBS 139058

CBS 139068

CBS 109505

CBS 141333

CBS 958.97

BCC 28876

BCC 28877

CBS 541.72

CBS 237.48

CBS 102374

MFLUCC 14-0651

MTCC 11985

CBS 115206

CBS 397.59

CBS 262.69

Kruys 201

MFLUCC 11-0514

MFLUCC 12-0545

CBS 127882

CBS 139062

CBS 139064

CBS 139063

CBS 139066

CBS 139070

BCC 4027

BCC 18525

BCC 20803

BCC 40633

URM 7413 (CBS 141536)

URM 7414 (CBS 141535)
GenBank accession numbers

LSU SSU TEF1- $\alpha$ ITS

JX444874 JX444902 - $\quad$ KF766178

JX444883 JX444908 - $\quad$ KF766185

FJ795507 GU456308 GU456289 -

KP687861 KP687968 KP688030 KP687861

KP687885 KP687979 KP688053 KP687885

GU456324 GU456303 GU456260 -

KX228339 - $\quad-\quad$ - $\quad K X 228288$

GU301855 GU296181 GU349038 -

GU371836 GU371828 - - -

GU371837 GU371829 - - -

AY004340 AY016348 DQ677892 -

DQ678085 DQ678034 - _ -

GU301815 GU296151 GU349053 FJ538313

KT306952 KT306955 - KT306948

KM052851 KM052852 - KM052850

GU301869 GU296194 GU349030 KF766226

KR869797 - $\quad$ - $\quad$ KR822200

GU348996 GU349000 GU349020 -

DQ384096 DQ384070 - _ -

KF301538 KF301543 KF301557 KF301530

KJ880036 KJ880035 KJ880037 KJ880034

KP687886 KP687980 KP688054 KP687886

KP687868 KP687972 KP688037 KP687868

KP687874 KP687974 KP688042 KP687874

KP687870 KP687973 KP688039 KP687870

KP687879 KP687976 KP688047 KP687879

KP687843 КР687964 KР688013 КР687843

KJ425449 KJ425440 -

KJ425450 KJ425436 -

KJ425453 KJ425439 -

KJ425455 KJ425442 -

KX518625 KX518629 KX518633 KX470392

KX518626 KX518630 KX518634 KX470393

Sequences obtained in this study are shown in bold 


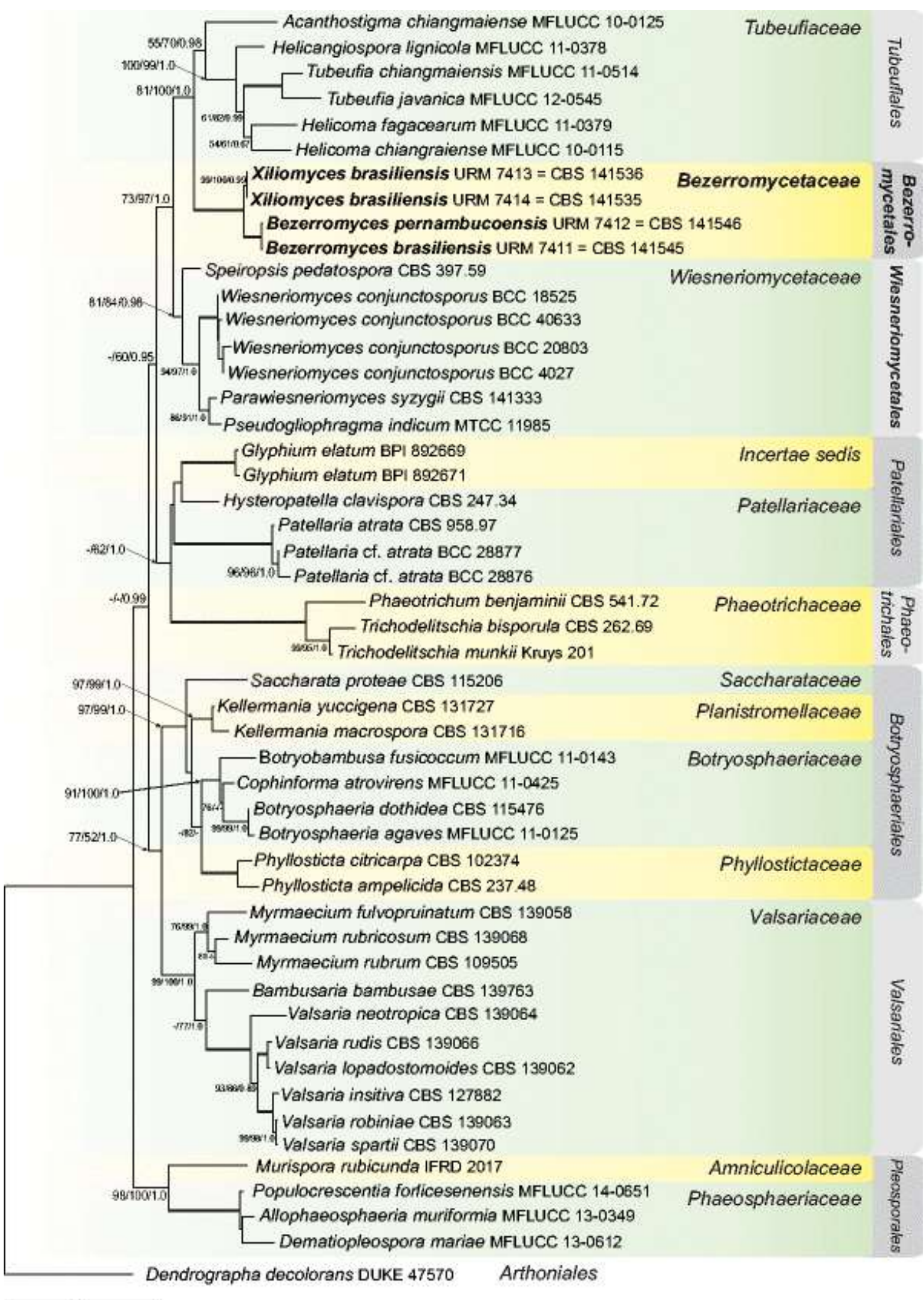

0.1

Fig. 1. Maximum likelihood (RAxML) tree obtained by phylogenetic analyses of the combined LSU nrDNA, SSU nrDNA, and tef1 alignment of 50 taxa belonging to the nine orders shown to the right of the tree. Bootstrap support values from maximum parsimony (MP-BS) and maximum likelihood (ML-BS), and Bayesian posterior probabilities (BPP) are indicated at the nodes (MP-BS/ML-BS/BPP). Thickened branches represent clades with $100 \%$ MP-BS and ML-BS, and a BPP = 1.0. The scalebar represents the number of changes. Dendrographa decolorans (Arthoniales) was used as outgroup 


\section{Results}

\section{DNA sequence alignments and phylogenetic analyses}

Following the results of preliminary phylogenetic analysis of the initial alignment (data not shown), the phylogenetic reconstruction of the second alignment was performed including sequences from 50 strains representing eight different orders in the Dothideomycetes and one order in the Arthoniomycetes, with the following distribution: Tubeufiales (6), Bezerromycetales ord. nov. (4), Wiesneriomycetales ord. nov. (7), Patellariales (6), Phaeotrichales (3), Botryosphaeriales (9), Valsariales (10), Pleosporales (4) and Arthoniales (1) (Table 1). The three-gene dataset comprised of LSU nrDNA sequences for all 50 ingroup sequences, $48 \mathrm{SSU}$ nrDNA sequences and 32 tef1 sequences. After exclusion of ambiguous regions and introns, the combined dataset included 2628 characters ( 736 for LSU nrDNA, 1015 for SSU nrDNA, and 877 for tef1). In the MP analysis, 1891 characters were constant, 185 were variable and parsimony-uninformative and 558 were parsimony-informative. In the BI analysis, 296, 253, and 354 unique site patterns were present for LSU, SSU and tef1, respectively.

The best tree (RAxML) obtained using the $M L$ analysis is shown as Fig. 1, with the support values from the MP, ML and $B I$ analyses plotted at the nodes. The sequences of the endophytic strains clustered together in a distinct clade, fully supported by all analyses (MP$\mathrm{BS}=100 \%, \mathrm{ML}-\mathrm{BS}=100 \%$, and $\mathrm{BPP}=1$ ), for which Bezerromycetales ord. nov. is proposed below. The order Tubeufiales is a sister lineage to Bezerromycetales ord. nov. and formed a distinct clade with high BPP support (MP-BS $=55 \%, \mathrm{ML}-\mathrm{BS}=70 \%$, and $\mathrm{BPP}=0.98$ ). We have observed that the family Wiesneriomcetaceae is positioned in a separate clade close to the new order and Tubeufiales with high support (MP-BS $=81 \%, \mathrm{ML}-\mathrm{BS}=100 \%$, and $\mathrm{BPP}=1$ ). Based on these results, we are introducing a new order, Wiesneriomycetales, below (MP$\mathrm{BS}=81 \%, \mathrm{ML}-\mathrm{BS}=84 \%$, and BPP $=0.98$ ). The Tubeufiales-BezerromycetalesWiesneriomycetales group (MP-BS $=73 \%, M L-B S=97 \%$, and $B P P=1$ ) is related to the orders Patellariales and Phaeotrichales, but with low support (ML-BS $=60 \%$, and BPP $=0.95$ ). In our analyses Tubeufiales is placed in a different phylogenetic position, compared to the phylogeny of Boonmee et al. (2014), where the order Tubeufiales was positioned as a separate lineage between Botryosphaeriales and Patellariales. Phylogenetic analyses with $M P, M L$, and $\mathrm{BI}$ using the dataset of individual loci were also performed, but no topological phylogenetic conflict was observed (data not shown).

\section{Taxonomy}

Bezerromycetales J.D.P. Bezerra, C.M. Souza-Motta \& Crous, ord. nov.

MycoBank MB817520

Ascomata superficial or immersed in culture media, pseudothecial, unilocular, globose to subglobose, gregarious or solitary, pale brown to brown at maturity, minutely papillate with ostiole, collapsing cupulate or laterally, smooth or hairy. Peridium comprising pale brown cells of textura angularis, and small cells of textura prismatica. Hamathecium comprising of numerous, filiform, septate, branched, hyaline pseudoparaphyses. Asci 8-spored, bitunicate, 
fissitunicate, cylindrical to cylindrical-clavate, short pedicellate, with or without a minute ocular chamber. Ascospores 1-2-seriate in ascus, hyaline when young, becoming pale brown to brown at maturity, ellipsoidal, muriformly septate, smooth or minutely verrucose.

Chlamydospores sometimes linked to ascomata by hyphae, multiseptate, brown, dictyochlamydospore-like, globose to subglobose or ellipsoid to cylindrical. Asexual morph unknown. Known only as endophytic fungi associated with cactus species in tropical dry forests.

Type family: Bezerromycetaceae J.D.P. Bezerra, C.M. Souza-Motta \& Crous.

Bezerromycetaceae J.D.P. Bezerra, C.M. Souza-Motta \& Crous, fam. nov.

MycoBank MB817521

Morphological characters similar as for Bezerromycetales.

Type genus: Bezerromyces J.D.P. Bezerra, C.M. Souza-Motta \& Crous.

Included genera: Bezerromyces J.D.P. Bezerra, C.M. Souza-Motta \& Crous, Xiliomyces J.D.P. Bezerra, C.M. Souza-Motta \& Crous.

Bezerromyces J.D.P. Bezerra, C.M. Souza-Motta \& Crous, gen. nov.

MycoBank MB817522

Etymology: Named in honour of José Luiz Bezerra (J.L. Bezerra), an extraordinary mycologist from the previous Institute of Mycology at the University of Recife (IMUR), Pernambuco, Brazil.

Ascomata superficial or immersed in culture media, pseudothecial, unilocular, globose to subglobose, to $330 \mu \mathrm{m}$ diam, gregarious or solitary, pale brown to brown at maturity, minutely papillate with ostiole, collapsing cupulate or laterally, hairy. Peridium comprising pale brown cells of textura angularis, and small cells of textura prismatica. Hamathecium comprising of numerous, filiform, septate, branched, hyaline pseudoparaphyses. Asci 8spored, bitunicate, fissitunicate, cylindrical to cylindrical-clavate, short pedicellate, with or without a minute ocular chamber. Ascospores 1-2-seriate in ascus, hyaline when young, becoming pale brown to brown at maturity, ellipsoidal, muriformly septate, smooth. Chlamydospores sometimes linked to ascomata by hyphae, multiseptate, dictyochlamydospore-like, ellipsoid to cylindrical. Asexual morph unknown.

Type species. Bezerromyces brasiliensis J.D.P. Bezerra, C.M. Souza-Motta \& Crous.

Bezerromyces brasiliensis J.D.P. Bezerra, C.M. Souza-Motta \& Crous, sp. nov.

MycoBank MB 817523. Figure 2. 

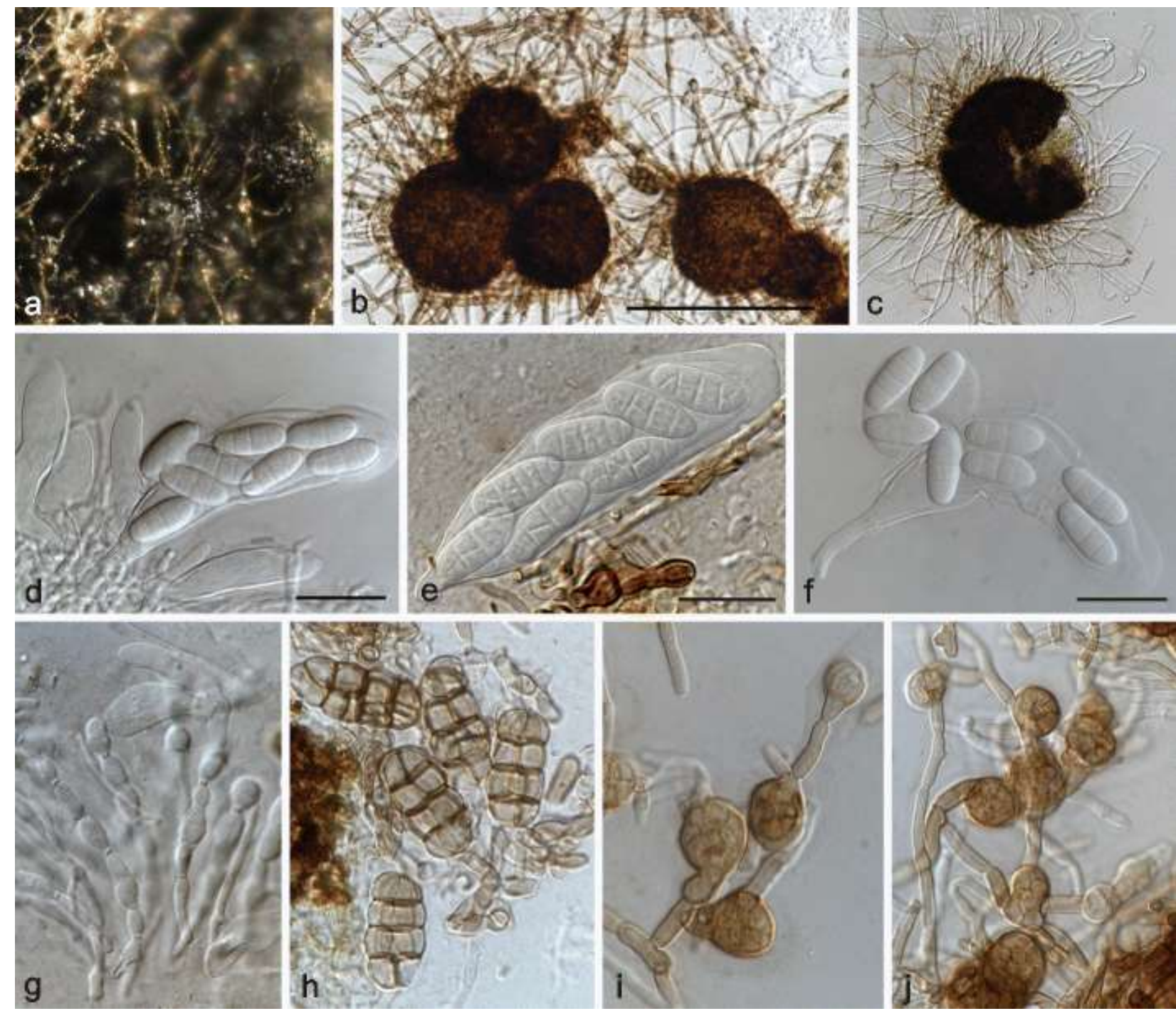

Fig. 2. Bezerromyces brasiliensis (URM $7411=$ CBS 141545). a Ascomata superficial on WA medium. b, c Ascomata pseudothecial (in 85\% lactic acid). $\mathbf{d}-\mathbf{f}$ Asci and ascospores. $\mathbf{g}$ Pseudoparaphyses. $\mathbf{h}$ Ascospores germinating. i, j Chlamydospores. Scale bars (b, c) $250 \mu \mathrm{m},(\mathbf{d}) 30 \mu \mathrm{m},(\mathbf{e}) 20 \mu \mathrm{m},(\mathbf{f}-\mathbf{j}) 30 \mu \mathrm{m}$

Etymology: Name reflects the country (Brazil) where J.L. Bezerra was born.

Ascomata superficial or immersed in WA and SNA culture media, pseudothecial, unilocular, globose to subglobose, gregarious or solitary, pale brown to brown at maturity, minutely papillate with ostiole, collapsing cupulate or laterally, hairy, 86-207 $\mu \mathrm{m}$ high and 110$203 \mu \mathrm{m}$ diam. Peridium comprising of pale brown cells of textura angularis, and small textura prismatica. Hamathecium comprising of numerous, filiform, septate, branched, hyaline pseudoparaphyses, sometimes inflated, 2-7 $\mu \mathrm{m}$ wide. Asci 8-spored, bitunicate, fissitunicate, cylindrical to cylindrical-clavate, short pedicellate, with or without a minute ocular chamber, 89-138 × 19.5-28.5 $\mu \mathrm{m}$. Ascospores 1-2-seriate in ascus, hyaline when young, becoming pale brown to brown at maturity, ellipsoidal, muriformly septate, smooth, 2-4 vertical septa and 3 transverse septa, 12-33 × 8-15.5 $\mu \mathrm{m}$. Chlamydospores sometimes linked to ascomata by hyphae, multiseptate, dictyochlamydospore-like, globose to subglobose or cylindrical, $13.5-27.5 \times 20.5-40 \mu \mathrm{m}$. Asexual morph unknown. 
Culture characteristics: Colonies on MEA and PDA are similar, velvety, surface and reverse dark olive to brown, growing up to $5 \mathrm{~cm}$ at room temperature $\left(22^{\circ} \mathrm{C}\right)$ in one month.

Specimen examined: Brazil, Pernambuco, Catimbau National Park ( $\left.8^{\circ} 36^{\prime} 35^{\prime \prime} \mathrm{S}, 37^{\circ} 14^{\prime} 40^{\prime \prime} \mathrm{W}\right)$, as endophytic fungus from cactus Tacinga inamoena, Sep. 2013, J.D.P. Bezerra (holotype URM 89943; isotype CBS H-22686; culture ex-type URM 7411 = CBS 141545).

Bezerromyces pernambucoensis J.D.P. Bezerra, C.M. Souza-Motta \& Crous, sp. nov.

MycoBank MB817524. Figure 3.
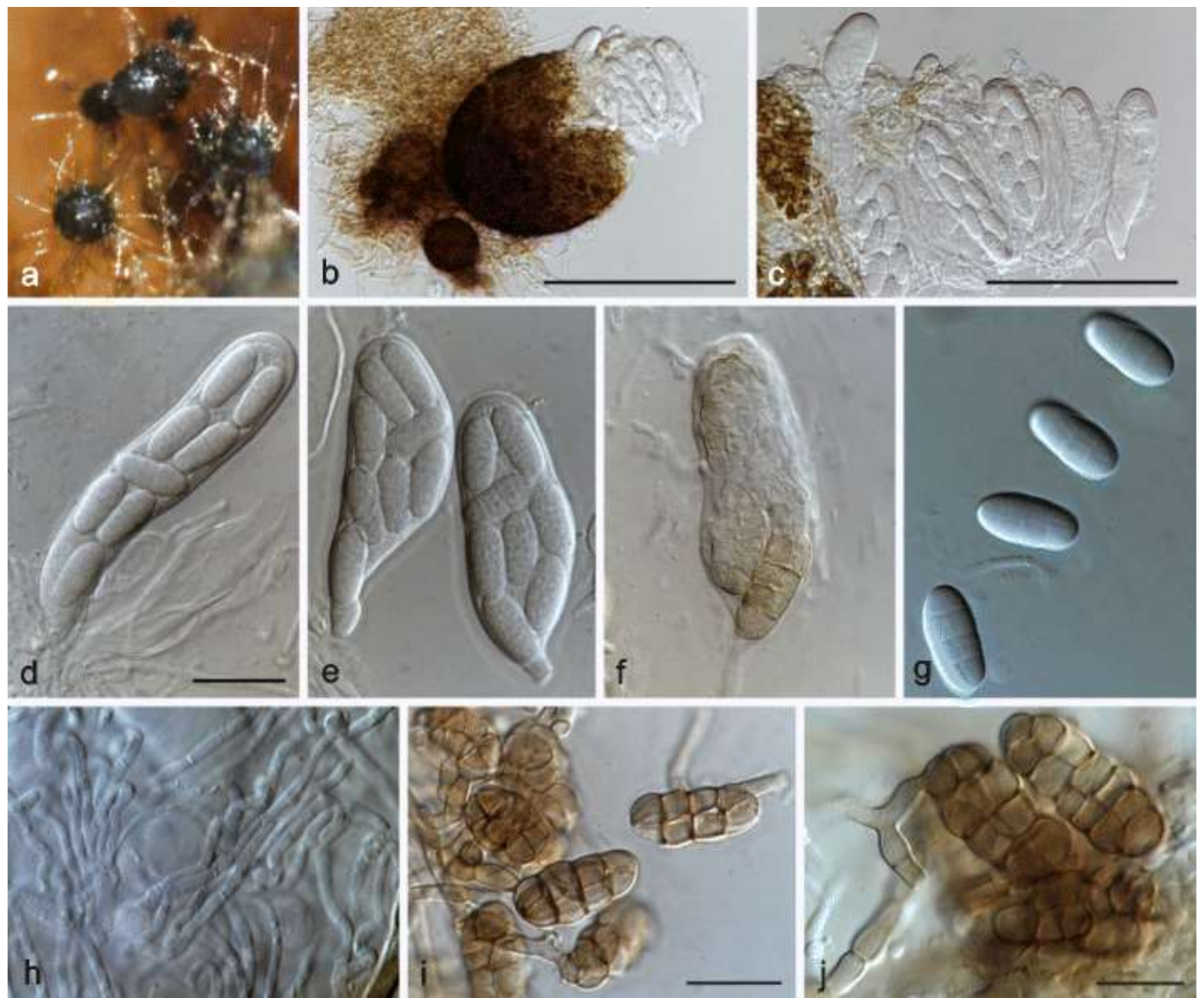

Fig. 3. Bezerromyces pernambucoensis (URM 7412 = CBS 141546). a Ascomata superficial on WA medium. b Ascomata pseudothecial and asci. c Asci, ascospores and pseudoparaphyses. $\mathbf{d}-\mathbf{f}$ Asci and ascospores. $\mathbf{g}$ Ascospores. h Pseudoparaphyses. i, j Ascospores germinating. Scale bars (b) $220 \mu \mathrm{m}$, (c) $100 \mu \mathrm{m},(\mathbf{d}-\mathbf{h}) 30 \mu \mathrm{m}$, (i) $25 \mu \mathrm{m},(\mathbf{j}) 15 \mu \mathrm{m}$

Etymology: Name reflects the Brazilian state (Pernambuco), where J.L. Bezerra was born.

Ascomata superficial or immersed in WA and SNA culture media, pseudothecial, unilocular, globose to subglobose, gregarious or solitary, liked by hyphae, pale brown to brown at maturity, minutely papillate with ostiole, collapsing cupulate or laterally, hairy, $130-380 \mu \mathrm{m}$ high and 135-330 $\mu \mathrm{m}$ diam. Peridium comprising of pale brown cells of textura angularis, 
and small textura prismatica. Hamathecium comprising of numerous, filiform, septate, branched, hyaline pseudoparaphyses, 2.3-3.2 $\mu \mathrm{m}$ wide. Asci 8-spored, bitunicate, fissitunicate, cylindrical to cylindric-clavate, short pedicellate, with or without a minute ocular chamber, 60.5-114 × 20.5-31.5 $\mu \mathrm{m}$. Ascospores 1-2-seriate in ascus, hyaline when young, becoming pale brown to brown at maturity, ellipsoidal, muriformly septate, smooth, 2-4 vertical septa and 3 transverse septa, 10.5-36 × 7.5-14.8 $\mu \mathrm{m}$. Chlamydospores sometimes linked to ascomata by hyphae, multiseptate, dictyochlamydospore-like, ellipsoid to cylindrical, $13.5-38 \times 20-40.5 \mu \mathrm{m}$. Asexual morph unknown.

Culture characteristics: Colonies on MEA and PDA are velvety, surface and reverse dark olive to brown, growing up to $5 \mathrm{~cm}$ at room temperature $\left(22^{\circ} \mathrm{C}\right)$ in 1 month.

Specimen examined: Brazil, Pernambuco, Catimbau National Park ( $\left.8^{\circ} 36^{\prime} 35^{\prime \prime} \mathrm{S}, 37^{\circ} 14^{\prime} 40^{\prime \prime} \mathrm{W}\right)$, as endophytic fungus from cactus Tacinga inamoena, Sep 2013, J.D.P. Bezerra (holotype URM 89944; isotype CBS H-22687; culture ex-type URM 7412 = CBS 141546).

Notes: Bezerromyces brasiliensis and B. pernambucoensis differ in ascomata, asci, and ascospore size. Bezerromyces differs from Populocrescentia (Ariyawansa et al. 2015), Dematiopleospora and Allophaeosphaeria (Wanasinghe et al. 2014; Liu et al. 2015) in peridium structure, papillate ostiole, ascomata shape, muriform and fusiform ascospores. Also, it can be differentiated from Murispora (Zhang et al. 2009) forming muriform and fusiform ascospores, and having a phoma-like asexual morph (Wanasinghe et al. 2015). All of these genera are affiliated to Pleosporales, which is phylogenetically distant from Bezerromyces.

Xiliomyces J.D.P. Bezerra, C.M. Souza-Motta \& Crous, gen. nov.

MycoBank MB817525.

Etymology: Named in honour of the Maria Auxiliadora de Queiroz Cavalcanti (Xilia), a mycologist from the previous Institute of Mycology at the University of Recife (IMUR), Pernambuco, Brazil.

Ascomatal structures superficial or immersed in culture media, pseudothecial-like, unilocular, globose to subglobose, up to $188 \mu \mathrm{m}$ diam, gregarious or solitary, pale brown to brown at maturity, minutely papillate with ostiole, smooth. Chlamydospores multiseptate, dictyochlamydospore-like, globose to subglobose, up to $26 \mu \mathrm{m}$ diam.

Type species: Xiliomyces brasiliensis J.D.P. Bezerra, C.M. Souza-Motta \& Crous.

Xiliomyces brasiliensis J.D.P. Bezerra, C.M. Souza-Motta \& Crous, sp. nov.

MycoBank MB817526. Figure 4. 

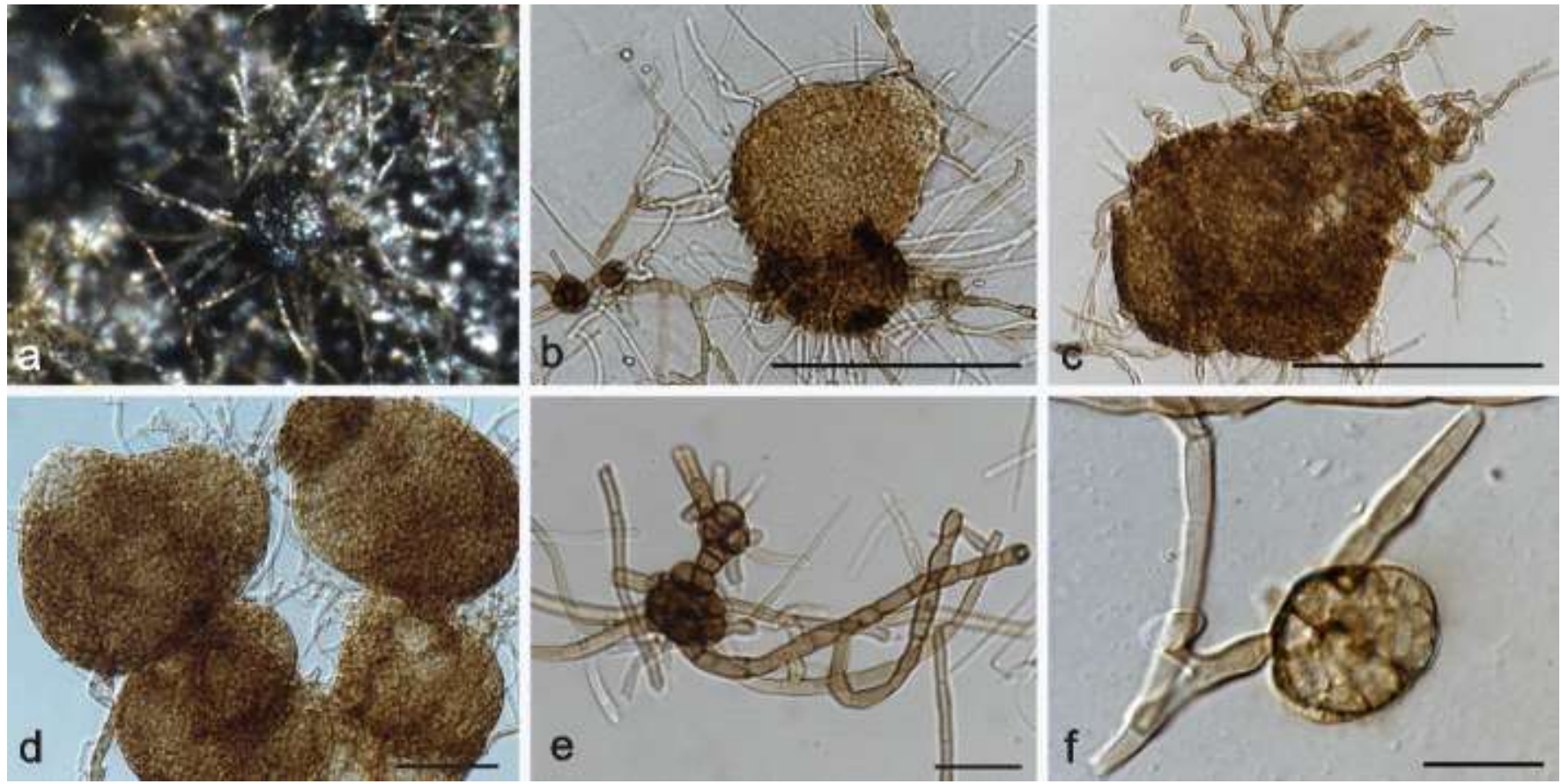

Fig. 4. Xiliomyces brasiliensis (URM $7413=$ CBS 141536). a Ascomatal structures superficial on WA medium. bd Ascomatal structures pseudothecial-like. e, f Chlamydospores. Scale bars (b) $250 \mu \mathrm{m}$, (c) $175 \mu \mathrm{m}$, (d) $100 \mu \mathrm{m}$, (e) $25 \mu \mathrm{m}$, (f) $15 \mu \mathrm{m}$

Etymology: Name reflects the country (Brazil) where M.A.Q. Cavalcanti was born.

Xiliomyces brasiliensis differs from B. brasiliensis and B. pernambucoensis by unique fixed alleles based on alignment of the combined LSU nrDNA, SSU nrDNA and tef1 loci deposited in TreeBASE (S19537) and ITS nrDNA sequences deposited in GenBank: LSU nrDNA positions 164 (C), 456 (G), 661 (gap), and 663 (C); SSU nrDNA position 740 (C), 741 (C), 742 (G), 743 $(T), 745(A)$, and $746(A)$; tef1 positions 1824 (C), 1830 (C), 1869 (G), 1899 (C), 2034 (T), 2088 (C), 2103 (C), 2110 (G), 2128 (G), 2136 (C), 2212 (G), 2300 (A), 2341 (G), 2344 (C), 2380 (C), 2406 (A), 2416 (G), 2424 (A), 2527 (C), 2590 (C), 2605 (G), and 2629 (C); ITS nrDNA positions $73(\mathrm{C}), 79(\mathrm{C})$, and $185(\mathrm{C})$.

Culture characteristics: Colonies on MEA and PDA are velvety, surface and reverse dark olive to brown, growing up to $5 \mathrm{~cm}$ at room temperature $\left(22^{\circ} \mathrm{C}\right)$ in 1 month.

Specimens examined: Brazil, Pernambuco state, Itaíba municipality, Curral Velho farm $\left(9^{\circ} 08.895 \mathrm{~S}, 37^{\circ} 12.069 \mathrm{~W}\right)$, as endophytic fungi from cactus Tacinga inamoena, Sep. 2013, J.D.P. Bezerra (holotype URM 89945; isotype CBS H-22680; culture ex-type URM 7413 = CBS 141536; ibid. URM 7414 = CBS 141535).

Notes: Xiliomyces brasiliensis is described here without well-defined sexual or asexual structures. After more than 5 months of incubation under different conditions and culture media, with and without sterilized cactus tissues, we observed only ascomatal-like structures and chlamydospores. A blast search of GenBank using the SSU and LSU nrDNA sequences demonstrated the close relationship with genera in Tubeufiales (SSU nrDNA: identities = 98-99\%; LSU nrDNA: identities =94-95\%); tef1 sequences demonstrated low identities with genera belonging to Pleosporales. The ITS nrDNA sequences have distant similarity to uncultured fungi [e.g. GenBank JX136098; Identities 482/531 (91\%), Gaps 
17/531 (3\%)], fungi from rock formations [e.g. GenBank AY843120; Identities 451/491 (92\%), Gaps 17/491 (3\%)], and fungal endophyte from Juniperus deppeana [e.g. GenBank KP991001; Identities 428/454 (94\%), Gaps 11/454(2\%)]. In the phylogenetic tree (Fig. 1), the Xiliomyces sequences cluster as a sister lineage to Bezerromyces in the Bezerromycetales.

Wiesneriomycetales J.D.P. Bezerra, R.J.V. Oliveira, C.M. Souza-Motta, J.Z. Groenewald \& Crous, ord. nov.

MycoBank MB818886

Conidiomata sporodochial, synnematal, solitary to gregarious, with or without setae. Setae subulate, septate, erect, flexuous, pigmented, thick-walled. Conidiophores macronematous, mononematous, penicillate, septate, branched, straight or flexuous, solitary or gregarious. Conidiogenous cells holoblastic, monoblastic, polyblastic, discrete, determinate, terminate, clavate, cylindrical, slightly ampulliform. Conidia solitary to gregarious, hyaline, pale, aseptate, catenate, connected by narrow isthmi, fusiform to falcate, cylindrical, subcylindrical, cuneiform, branched. Sexual morph unknown.

Type family: Wiesneriomycetaceae Suetrong, Rungjindamai, Somrithipol. \& E.B.G. Jones

Wiesneriomycetaceae Suetrong, Rungjindamai, Somrithipol. \& E.B.G. Jones, Phytotaxa 176: 288. 2014.

Description: see Suetrong et al. (2014) and similar as for Wiesneriomycetales.

Type genus: Wiesneriomyces Koord.

Included genera: Wiesneriomyces Koord., Verh. K. Akad. Wet., tweede sect. 13: 246. 1907, Pseudogliophragma Phadke \& V.G. Rao, Norw. JI Bot. 27: 127. 1980, Speiropsis Tubaki, J. Hattori bot. Lab. 20: 171. 1958, Parawiesneriomyces Crous \& M.J. Wingf., Persoonia 36: 389. 2016.

Notes: Based on our phylogenetic analyses, the order Wiesneriomycetales is introduced to accommodate the family Wiesneriomycetaceae. Fungi in this order are characterized by sporodochial or synnematal conidiomata with or without setae; conidiophores are macronematous, mononematous or penicillate; conidia hyaline to slightly pigmented in chains connected by narrow isthmi. To date no sexual morph is known for any of these genera. These fungi have a wide distribution in tropical and subtropical regions, growing on different substrates (Suetrong et al. 2014; Pratibha et al. 2015; Santos 2015; Crous et al. 2016). In addition, some authors have circumscribed Speiropsis as an aquatic hyphomycete (Barbosa and Gusmão 2005; Santos 2015).

\section{Discussion}

Studies of endophytic fungi in different countries have revealed a huge fungal diversity associated with plants growing in distinct biomes (Bezerra et al. 2015; Massimo et al. 2015; Nascimento et al. 2015; Fonseca-García et al. 2016; Siddique and Unterseher 2016). Several taxa have been described based on endophytic isolates, and have contributed to the 
discussion of fungal-host relationships, taxonomic novelties and ecological distribution (Siqueira et al. 2008; Glienke et al. 2011; Oliveira et al. 2014, 2016; Knapp et al. 2015). These molecular data have greatly improved our understanding of phylogenetic relationships, clarifying fungal classification including new fungi from different environments, with the aim of establishing their global distribution and diversity (Kirk et al. 2013; Crous et al. 2014a, b, $2015 a, b)$.

Studies on endophytic fungi have directly contributed to fungal diversity estimates with new taxa associated with distinct biomes around the world (Fisher et al. 1993; Dreyfuss and Chapela 1994; Strobel and Daisy 2003; Kemler et al. 2013). These morphological characters and molecular data are crucial to describing these new taxa, and for clarifying obstacles in understanding dothideomycete systematics (Schoch et al. 2009). Our study again underlined the importance of these microorganisms for fungal taxonomy, and the need for preservation of these cactus species and environments.

The new order Bezerromycetales is proposed here to accommodate a new family, Bezerromycetaceae. A preliminary phylogenetic analysis using 219 representative taxa of Dothideomycetes, Eurotiomycetes and Lecanoromycetes based on Boehm et al. (2015) revealed Bezerromycetales as a unique clade related to Tubeufiales (data not shown). Different phylogenetic analyses using three loci (SSU nrDNA, LSU nrDNA and tef1) and morphological characters, such as the muriformly septate ascospores, supported this clade as new order in the class Dothideomycetes. Tubeufiales was proposed by Boonmee et al. (2014) based on morphological characteristics and DNA sequences to accommodate the unique family Tubeufiaceae, which now has 19 accepted genera, including asexual and sexual morphs. This order is characterised by having superficial, oval and bright ascomata, bitunicate asci, mostly with long fusiform to filiform, transeptate ascospores, and having hyphomycetous asexual morphs with helicosporous conidia (Boonmee et al. 2014).

In addition, representative sequences from the family Wiesneriomycetaceae, proposed by Suetrong et al. (2014) as order incertae sedis, represented a strongly supported clade closely related to the new order Bezerromycetales and Tubeufiales. In their study, the phylogenetic analyses of Suetrong et al. (2014) showed Wiesneriomycetaceae as a monophyletic clade between Patellariales and Tubeufiales, with Tubeufiales as closest sister group. This family is morphologically characterized by sporodochial conidiomata with setae, macronematous and branched conidiophores, and hyaline to slightly pigmented conidia in uniseriate chains connected by narrow isthmi, lacking a sexual morph (Suetrong et al. 2014). Pratibha et al. (2015) included the genus Pseudogliophragma in this family and placed Wiesneriomycetaceae in the order Tubeufiales. Another study by Santos (2015) included the genus Speiropsis in this family and proposed Pseudogliophragma as synonym of Wiesneriomyces. Recently, Crous et al. (2016) included the novel monotypic genus Parawiesneriomyces in the Wiesneriomycetaceae. Based on these morphological characteristics and on the results obtained in our phylogenetic analyses, we are introducing the order Wiesneriomycetales to accommodate the family Wiesneriomycetaceae.

The class Dothideomycetes is one of the most important and diverse classes in the phylum Ascomycota. It comprises phytopathogenic fungi, endophytes, fungi with different habits and habitats, and also fungi with biotechnological potential (Wijayawardene et al. 2014; 
Santos et al. 2015; Woudenberg et al. 2015). In recent years, this class has received significant attention and several papers have highlighted its importance to fungal taxonomy, based on its fungal diversity and on new studies performed to improve the classification of dothideomycetous fungi (Schoch et al. 2009; Hyde et al. 2013; Wijayawardene et al. 2014). Studies on fungal endophytes have contributed directly with new taxa added to the Dothideomycetes and contributed to the discussion on the origin of the association between plants and fungi (Slippers and Wingfield 2007; Glienke et al. 2011; Bezerra et al. 2012, 2013; Gomes et al. 2013; Phillips et al. 2013; Knapp et al. 2015).

Several new genera were recently described with phenotypic characteristics, such as muriformly septate ascospores, similar to Bezerromyces, but these were placed in other families and orders. The genus Populocrescentia was described by Ariyawansa et al. (2015) as saprobic on dead and hanging branches of Populus nigra collected in Italy. This genus belongs to the family Phaeosphaeriaceae (Pleosporales) and is also distinct from Dematiopleospora and Allophaeosphaeria (both Pleosporales) in its peridium structure, papillate ostioles, ascomata shape, muriform and fusiform ascospores (Wanasinghe et al. 2014; Liu et al. 2015). Another genus, Murispora (Zhang et al. 2009), has a freshwater habitat and is saprobic, characterised by muriform and fusiform ascospores, and is placed in the family Amniculicolaceae (Pleosporales); recently, additional novel species, including some with phoma-like asexual morphs, have been included in this genus by Wanasinghe et al. (2015). The orders phylogenetically closely related to Bezerromycetales, such as Botryosphaeriales (Schoch et al. 2006; Slippers et al. 2013), Tubeufiales (Boonmee et al. 2014), and Wiesneriomycetales ord. nov. have different sexual and asexual morphological characters (ascomata and asci shape, ascospores shape, septation, and asexual morphs), and are phylogenetically distinct from Bezerromycetales. The description of Bezerromycetales as a new order in the present study highlights the need to collect fungal biodiversity from a range of diverse environments and substrates, as these diverse niches frequently harbour fungal lineages that are still missing in current phylogenetic studies.

\section{Acknowledgments}

We thank Conselho Nacional de Desenvolvimento Científico e Tecnológico (CNPq) (Process 203132/2014-9), Coordenação de Aperfeiçoamento de Pessoal de Nível Superior (CAPES) and Fundação de Amparo à Ciência e Tecnologia de Pernambuco (FACEPE) of Brazil for financial support of this project. We extend our thanks to the Universidade Federal de Pernambuco and to the mycologists Alexandre Machado, André Firmino, Eliane SilvaNogueira, Gianne Rizzuto, Greicilene Albuquerque, Karla Freire, and Renan Barbosa from URM Culture Collection, and to Arien van Iperen, Marcelo Denis, Marjan Vermaas, and Mieke Starink-Willemse from CBS. We also thank the students of the Laboratório de Micologia Ambiental/UFPE for their technical help and processing of samples.

\section{References}

Ariyawansa HA, Hyde KD, Jayasiri SC, Buyck B, Kandawatte WTC, Cui YY, Dai DQ, Dai YC, Daranagama DA, Jayawardena RS, Lücking R, Ghobad-Nejhad M, Niskanen T, Thambugala KM, Voigt K, Zhao RL, Boonmee S, Bahkali AH, Chen J, Cui BK, Dayarathne MC, Dissanayake AJ, Ekanayaka AH, Hashimoto A, Hongsanan S, Jones EBG, Larsson E, Lewis D, Li WJ, Li QR, Liu JK, Luo ZL, Maharachchikumbura SSN, Mapook A, McKenzie EHC, Norphanphoun C, Pang KL, Perera RH, Phookamsak R, Phukhamsakda C, Randrianjohany E, Senanayake IC, 
Singtripop C, Shang Q, Tanaka K, Tian Q, Tian CM, Tibpromma S, Verbeken A, Abdel-Wahab MA, Wanasinghe DN, Wijayawardene NN, Zhang JF, Zhang H, Abdel-Aziz FA, Adam č ík S, Ammirati JF, Bulgakov T, Cabral AL, Callaghan TM, Callac P, Chang CH, Coca LF, Dal-Forno M, Dollhofer V, Fliegerová K, Greiner K, Griffith GW, Ho HM, Hofstetter V, Jeewon R, Kang JC, Kirk PM, Kytövuori I, Lawrey JD, Li JXH, Liu ZY, Zhong XL, Liimatainen K, Lumbsch HT, Matumura M, Moncada B, Nuankaew S, Parnmen S, Santiago MDA, Sato G, Sommai S, Song Y, Souza CAF, Souza-Motta CM, Su HY, Suetrong S, Wang Y, Wei SF, Wen TC, Shen H, Yuan HS, Zhou LW, Reblova M, Fournier J, Camporesi E (2015) Fungal diversity notes 111-252 - taxonomic and phylogenetic contributions to fungal taxa. Fungal Divers 75:27-274. doi:10.1007/s13225-015-0346-5

Arnold AE, Maynard Z, Gilbert GS, Coley PD, Kursar TA (2000) Are tropical fungal endophytes hyperdiverse? Ecol Lett 3:267-274. doi:10.1046/j.1461-0248.2000.00159x

Barbosa FF, Gusmao LFP (2005) Two Speiropsis species (Anamorphic Fungi - Hyphomycetes) from Bahia State, Brazil. Acta Bot Bras 19:515-518

Bernard E, Penna LAO, Araújo E (2014) Downgrading, Downsizing, Degazettement, and Reclassification of Protected Areas in Brazil. Conserv Biol 28:939-950

Bezerra JDP, Santos MGS, Svedese VM, Lima DMM, Fernandes MJS, Paiva LM, Souza-Motta CM (2012) Richness of endophytic fungi isolated from Opuntia ficus-indica Mill. (Cactaceae) and preliminary screening for enzyme production. World J Microbiol Biotechnol 28:1989-1995

Bezerra JDP, Santos MGS, Barbosa RN, Svedese VM, Lima DMM, Fernandes MJS, Gomes BS, Paiva LM, AlmeidaCortez JS, Souza-Motta CM (2013) Fungal endophytes from cactus Cereus jamacaru in Brazilian tropical dry forest: a first study. Symbiosis 60:53-63

Bezerra JDP, Nascimento CCF, Barbosa RN, Silva DCV, Svedese VM, Silva-Nogueira EB, Gomes BS, Paiva LM, Souza-Motta CM (2015) Endophytic fungi from medicinal plant Bauhinia forficata: Diversity and biotechnological potential. Braz J Microbiol 46:49-57. doi:10.1590/S1517-838246120130657

Boehm EWA, Marson G, Mathiassen HG, Gardiennet A, Schoch LC (2015) An overview of the genus Glyphium and its phylogenetic placement in Patellariales. Mycologia 107:607-618

Boonmee S, Rossman AY, Liu JK, Li WJ, Dai DQ, Bhat JD, Jones EBG, McKenzie EHC, Xu JC, Hyde KD (2014) Tubeufiales, ord. nov., integrating sexual and asexual generic names. Fungal Divers 68:239-298

Cabral GAL, Sampaio EVSB, Almeida-Cortez J (2013) Estrutura Espacial e Biomassa da Parte Aérea em Diferentes Estádios Sucessionais de Caatinga, Santa Terezinha-PB. Rev Bras Geogr Física 6:566-574

Chandra S (2012) Endophytic fungi: novel sources of anticancer lead molecules. Appl Microbiol Biotechnol 95:47-59

Crous PW, Gams W, Stalpers JA, Robert V, Stegehuis G (2004) MycoBank: an online initiative to launch mycology into the 21st century. Stud Mycol 50:19-22

Crous PW, Verkley GJM, Groenewald JZ, Samson RA (2009) Fungal Biodiversity. CBS Laboratory Manual Series. Centraalbureau voor Schimmelcultures, Utrecht, The Netherlands

Crous PW, Giraldo A, Hawksworth DL, Robert V, Kirk PM et al (2014a) The Genera of Fungi: fixing the application of type species of generic names. IMA Fungus 5:141-160

Crous PW, Shivas RG, Quaedvlieg W, van der Bank M, Zhang Y et al (2014b) Fungal planet description sheets: 214-280. Persoonia 32:184-306 
Crous PW, Schumacher RK, Wingfield MJ, Lombard L, Giraldo A, Christensen M, Gardiennet A, Nakashima C, Pereira O, Smith AJ, Groenewald JZ (2015a) Fungal systematics and evolution: FUSE 1. Sydowia 67:81-118

Crous PW, Carris LM, Giraldo A, Groenewald JZ, Hawksworth DL, Hernández-Restrepo M, Jaklitsch WM, Lebrun M-H, Schumacher RK, Stielow JB, van der Linde EJ, Vilcane J, Voglmayr H, Wood AR (2015b) The Genera of Fungi - fixing the application of the type species of generic names - G 2: Allantophomopsis, Latorua, Macrodiplodiopsis, Macrohilum, Milospium, Protostegia, Pyricularia, Robillarda, Rotula, Septoriella, Torula, and Wojnowicia. IMA Fungus 6:163-198

Crous PW, Wingfield MJ, Richardson DM, Leroux JJ, Strasberg D, Edwards J, Roets F, Hubka V, Taylor PWJ, Heykoop M, Martín MP, Moreno G, Sutton DA, Wiederhold NP, Barnes CW, Carlavilla JR, Gené J, Giraldo A, Guarnaccia V, Guarro J, Hernández-Restrepo M, Kolařík M, Manjón JL, Pascoe IG, Popov ES, Sandoval-Denis M, Woudenberg JHC, Acharya K, Alexandrova AV, Alvarado P, Barbosa RN, Baseia IG, Blanchette RA, Boekhout T, Burgess TI, Cano-Lira JF, Čmoková A, Dimitrov RA, My D, Dueñas M, Dutta AK, Esteve-Raventós F, Fedosova AG, Fournier J, Gamboa P, Gouliamova DE, Grebenc T, Groenewald M, Hanse B, Hardy GESJ, Held BW, Jurjević Ž, Kaewgrajang T, Latha KPD, Lombard L, Luangsa-ard JJ, Lysková P, Mallátová N, Manimohan P, Miller AN, Mirabolfathy M, Morozova OV, Obodai M, Oliveira NT, Ordóñez ME, Otto EC, Paloi S, Peterson SW, Phosri C, Roux J, Salazar WA, Sánchez A, Sarria GA, Shin H-D, Silva BDB, Silva GA, Smith MT, Souza-Motta CM, Stchigel AM, Stoilova-Disheva MM, Sulzbacher MA, Telleria MT, Toapanta C, Traba JM, Valenzuela-Lopez N, Watling R, Groenewald JZ (2016) Fungal Planet description sheets: 400-468. Persoonia 36:316-458

Dreyfuss MM, Chapela IH (1994) Potential of fungi in the discovery of novel, low-molecular weight pharmaceuticals. In: Gullo VP (ed) The discovery of natural products with therapeutic potential. ButterworthHeinemann, London, pp 49-80

Fisher PJ, Petrini O, Sutton BC (1993) A comparative study of fungal endophytes in leaves, xylem and bark of Eucalyptus nitens in Australia and England. Sydowia 45:338-345

Fisher PJ, Sutton BC, Petrini LE, Petrini O (1994) Fungal endophytes from Opuntia stricta: a first report. Nova Hedwigia 59:195-200

Fonseca-García C, Coleman-Derr D, Garrido E, Visel A, Tringe SG, Partida-Martínez LP (2016) The cacti microbiome: interplay between habitat-filtering and host-specificity. Front Microbiol 7:150. doi:10.3389/fmicb.2016.00150

Freire KTLS, Araújo GR, Bezerra JDP, Barbosa RN, Silva DCV, Svedese VM, Paiva LM, Souza-Motta CM (2015) Fungos endofíticos de Opuntia ficus-indica (L.) Mill. (Cactaceae) sadia e infestada por Dactylopius opuntiae (Cockerell, 1896) (Hemiptera: Dactylopiidae). Gaia Sci 9:104-110

Glienke C, Pereira OL, Stringari D, Fabris J, Kava-Cordeiro V, Galli-Terasawa L, Cunnington J, Shivas RG, Groenewald JZ, Crous PW (2011) Endophytic and pathogenic Phyllosticta species, with reference to those associated with Citrus Black Spot. Persoonia 26:47-56

Gomes RR, Glienke C, Videira SIR, Lombard L, Groenewald JZ, Crous PW (2013) Diaporthe: a genus of endophytic, saprobic and plant pathogenic fungi. Persoonia 31:1-41. doi:10.3767/003158513X666844

Groenewald JZ, Nakashima C, Nishikawa J, Shin HD, Park JH, Jama AN, Groenewald M, Braun U, Crous PW (2013) Species concepts in Cercospora: spotting the weeds among the roses. Stud Mycol 75:115-170

Hubbard M, Germida JJ, Vujanovic V (2014) Fungal endophytes enhance wheat heat and drought tolerance in terms of grain yield and second-generation seed viability. J Appl Microbiol 116:109-122. doi:10.1111/jam.12311

Hyde KD, Jones EBG, Liu JK, Ariyawansha H, Eric B, Boonmee S, Braun U, Chomnunti P, Crous PW, Dai D, Diederich P, Dissanayake A, Doilom M, Doveri F, Hongsanan S, Jayawardena R, Lawrey JD, Li YM, Liu YX, Lücking 
R, Monkai J, Nelson MP, Phookamsak R, Muggia L, Pang KL, Senanayake I, Shearer CA, Wijayawardene N, Wu HX, Thambugala KM, Suetrong S, Tanaka K, Wikee S, Zhang Y, Aguirre-Hudson B, Alias SA, Aptroot A, Bahkali AH, Bezerra JL, Bhat JD, Binder M, Camporesi E, Chukeatirote E, Hoog SD, Gueidan C, Hawksworth DL, Hirayama K, Kang JC, Knudsen K, Li WJ, Liu ZY, Mapook A, Raja HA, Tian Q, Scheuer C, Schumm F, Taylor J, Yacharoen S, Tibpromma S, Wang Y, Yan JY, Zhang M (2013) Families of Dothideomycetes. Fungal Divers 63:1313

Jaklitsch WM, Fournier J, Dai DQ, Hyde KD, Voglmayr H (2015) Valsaria and the Valsariales. Fungal Divers 73:159-202

Jia M, Chen L, Xin H-L, Zheng C-J, Rahman K, Han T, Qin L-P (2016) A Friendly Relationship between Endophytic Fungi and Medicinal Plants: A Systematic Review. Front Microbiol 7:906

Katoh K, Standley DM (2013) MAFFT multiple sequence alignment software version 7: improvements in performance and usability. Mol Biol Evol 30:772-780

Kearse M, Moir R, Wilson A, Stones-Havas S, Cheung M, Sturrock S, Buxton S, Cooper A, Markowitz S, Duran C, Thierer T, Ashton B, Mentjies P, Drummond A (2012) Geneious Basic: an integrated and extendable desktop software platform for the organization and analysis of sequence data. Bioinformatics 28:1647-1649

Kemler M, Garnas J, Wingfield MJ, Gryzenhout M, Pillay K-A, Slippers B (2013) Ion torrent PGM as tool for fungal community analysis: a case study of endophytes in Eucalyptus grandis reveals high taxonomic diversity. PLoS ONE 8(12):e81718. doi:10.1371/journal.pone.0081718

Kirk PM, Stalpers JA, Braun U, Crous PW, Hansen K et al (2013) A without-prejudice list of generic names of fungi for protection under the International Code of Nomenclature for algae, fungi, and plants. IMA Fungus 4:381-443

Knapp DG, Kovács GM, Zajta E, Groenewald JZ, Crous PW (2015) Dark septate endophytic pleosporalean genera from semiarid areas. Persoonia 35:87-100

Liu JK, Hyde KD, Jones EBG, Ariyawansa HA, Bhat DJ, Boonmee S, Maharachchikumbura SSN, Mckenzie EHC, Phookamsak R, Phukhamsakda C, Shenoy BD, Abdel-Wahab MA, Buyck B, Chen J, Chethana KWT, Singtripop C, Dai DQ, Dai YC, Daranagama DA, Dissanayake AJ, Doilom M, D'souza MJ, Fan XL, Goonasekara ID, Hirayama K, Hongsanan S, Jayasiri SC, Jayawardena RS, Karu-Narathna SC, Li WJ, Mapook A, Norphanphoun C, Pang KL, Perera RH, Peršoh D, Pinruan U, Senanayake IC, Somrithipol S, Suetrong S, Tanaka K, Thambugala KM, Tian Q, Tibpromma S, Udayanga D, Wijayawardene NN, Wanasinghe DN, Wisitrassameewong K, Zeng XY, Abdel-Aziz FA, Adamcík S, Bahkali AH, Boonyuen N, Bulgakov T, Callac P, Chomnunti P, Greiner K, Hashimoto A, Hofstetter V, Kang JC, Lewis D, Li XH, Liu XZ, Liu ZY, Matsumura M, Mortimer PE, Rambold G, Randrianjohany E, Sato G, Sri-Indrasutdhi V, Tian CM, Verbeken A, Von Brackel W, Wang Y, Wen TC, Xu JC, Yan JY, Zhao RL, Camporesi E (2015) Fungal diversity notes 1-110: taxonomic and phylogenetic contributions to fungal species. Fungal Divers 72:1-197

Maia LC, Carvalho Júnior AA, Cavalcanti LH, Gugliotta AM, Drechsler-Santos ER, Santiago ALMA, Cáceres MES, Gibertoni TB, Aptroot A, Giachini AJ, Soares AMS, Silva ACG, Magnago AC, Goto BT, Lira CRS, Montoya CAS, Pires-Zottarelli CLA, Silva DKA, Soares DJ, Rezende DHC, Luz EDMN, Gumboski EL, Wartchow F, Karstedt F, Freire FM, Coutinho FP, Melo GSN, Sotão HMP, Baseia IG, Pereira J, Oliveira JJS, Souza JF, Bezerra JL, Araujo Neta LS, Pfenning LH, Gusmão LFP, Neves MA, Capelari M, Jaeger MCW, Pulgarín MP, Junior NM, Medeiros PS, Friedrich RCS, Chikowski RS, Pires RM, Melo RF, Silveira RMB, Urrea-Valencia S, Cortez VG, Silva VF (2015) Diversity of Brazilian Fungi. Rodriguésia 66:1033-1045

Massimo NC, Nandi Devan MM, Arendt KR, Wilch MH, Riddle JM, Furr SH et al (2015) Fungal endophytes in aboveground tissues of desert plants: infrequent in culture, but highly diverse and distinctive symbionts. Microb Ecol 70:61-76. doi:10.1007/s00248-014-0563-6 
Meiado MV, Machado MC, Zappi DC, Taylor NP, Siqueira Filho JA (2015) Ecological attributes, geographic distribution and endemism of cacti from the São Francisco watershed. Gaia Sci 9:40-53

Murali TS, Suryanarayanan TS, Venkatesan G (2007) Fungal endophytes communities in two tropical forest of southern India: diversity and host affiliation. Mycol Prog 6:191-199

Nascimento TL, Oki Y, Lima DMM, Almeida-Cortez JS, Fernandes GW, Souza-Motta CM (2015) Biodiversity of endophytic fungi in different leaf ages of Calotropis procera and their antimicrobial activity. Fungal Ecol 14:7986

Nylander JAA (2004) MrModeltest 2.0. Program distributed by the author. Uppsala University, Uppsala

Oliveira RJV, Lima TEF, Cunha IB, Coimbra VRM, Silva GA, Bezerra JL, Cavalcanti MAQ (2014) Corniculariella brasiliensis, a new species of coelomycetes in the rhizosphere of Caesalpinia echinata (Fabaceae, Caesalpinioideae) in Brazil. Phys Chem Chem Phys 178:197-204

Oliveira RJV, Bezerra JL, Lima TEF, Silva GA, Cavalcanti MAQ (2016) Phaeosphaeria nodulispora, a new endophytic coelomycete isolated from tropical palm (Cocos nucifera) in Brazil. Nova Hedwigia 103:185-192

Phillips AJL, Alves A, Abdollahzadeh J, Slippers B, Wingfield MJ, Groenewald JZ, Crous PW (2013) The Botryosphaeriaceae: genera and species known from culture. Stud Mycol 76:51-167

Porras-Alfaro A, Bayman P (2011) Hidden fungi, emergent properties: endophytes and microbiomes. Annu Rev Phytopathol 49:291-315. doi:10.1146/annurev-phyto-080508-081831

Pratibha J, Nguyen HDT, Mel'nik VA, Bhat DJ, White GP, Seifert KA (2015) Lectotypification, epitypification, and molecular phylogeny of the synnematous hyphomycete Pseudogliophragma indicum, the second genus in the Wiesneriomycetaceae. Mycoscience 56:387-395

Redman RS, Sheehan KB, Stout RG, Rodriguez RJ, Henson JN (2002) Thermotolerance generated by plant/fungal symbiosis. Science 298:1581

Ronquist F, Teslenko M, van der Mark P, Ayres DL, Darling A, Höhna S, Larget B, Liu L, Suchard MA, Huelsenbeck JP (2012) MrBayes 3.2: Efficient Bayesian phylogenetic inference and model choice across a large model space. Syst Biol 61:539-542

Rosa LH, Vaz ABM, Caligiorne RB, Campolina S, Rosa CA (2009) Endophytic fungi associated with the Antarctic grass Deschampsia antarctica Desv. (Poaceae). Polar Biol 32:161-167

Santos TAB (2015) Relações filogenéticas dos complexos Stachybotrys-Memnoniella e PhalangisporaSpeiropsis-Wiesneriomyces. Dissertation, Universidade Federal de Pernambuco

Santos MGS, Bezerra JDP, Svedese VM, Sousa MA, Silva DCV, Maciel MHC, Paiva LM, Porto ALF, Souza-Motta CM (2015) Screening of endophytic fungi from cactus of the Brazilian tropical dry forest according to their Lasparaginase activity. Sydowia 67:147-156

Schoch CL, Shoemaker RA, Seifert KA, Hambleton S, Spatafora JW, Crous PW (2006) A multigene phylogeny of the Dothideomycetes using four nuclear loci. Mycologia 98:1041-1052

Schoch CL, Crous PW, Groenewald JZ, Boehm EWA, Burgess TI, de Gruyter J, de Hoog GS, Dixon LJ, Grube M, Gueidan C, Harada Y, Hatakeyama S, Hirayama K, Hosoya T, Huhndorf SM, Hyde KD, Jones EBG, Kohlmeyer J, Kruys A, Li YM, Lücking R, Lumbsch HT, Marvanova L, Mbatchou JS, McVay AH, Miller AN, Mugambi GK, Muggia L, Nelsen MP, Nelson P, Owensby CA, Phillips AJL, Phongpaichit S, Pointing SB, Pujade-Renaud V, Raja HA, Rivas PE, Robbertse B, Ruibal C, Sakayaroj J, Sano T, Selbmann L, Shearer CA, Shirouzu T, Slippers B, Suetrong S, 
Tanaka K, Volkmamm-Kohlmeyer B, Wingfield MJ, Wood AR, Woudenberg JHC, Yonezawa H, Zhang Y, Spatafora JW (2009) A class-wide phylogenetic assessment of Dothideomycetes. Stud Mycol 64:1-15

Siddique AB, Unterseher M (2016) A cost-effective and efficient for Illumina sequencing of fungal communities: A case study of beech endophytes identified elevation as main explanatory factor for diversity and community composition. Fungal Ecol 20:175-185

Silva-Hughes AF, Wedge DE, Cantrell CL, Carvalho CR, Pan Z, Moraes RM, Madoxx VL, Rosa LH (2015) Diversity and antifungal activity of the endophytic fungi associated with the native medicinal cactus Opuntia humifusa (Cactaceae) from the United States. Microbiol Res 175:67-77. doi:10.1016/j.micres.2015.03.007

Siqueira VM, Souza-Motta C, Braun U (2008) Corynespora subcylindrica sp. nov., a new hyphomycete species from Brazil and a discussion on the taxonomy of corynespora-like genera. Sydowia 60:113-122

Slippers B, Wingfield MJ (2007) Botryosphaeriaceae as endophytes and latent pathogens of woody plants: diversity, ecology and impact. Fungal Biol Rev 21:90-106

Slippers B, Boissin E, Phillips AJL et al (2013) Phylogenetic lineages in the Botryosphaeriales: a systematic and evolutionary framework. Stud Mycol 76:31-49

Stamatakis A, Hoover P, Rougemont J (2008) A rapid bootstrap algorithm for RAxML web-servers. Syst Biol 75:758-771

Strobel GA, Daisy B (2003) Bioprospecting for microbial endophytes and their natural products. Microbiol Mol Biol Rev 67:491-502

Suetrong S, Rungjindamai N, Sommai S, Rungareerate P, Sommrithipol S, Jones EBG (2014) Wiesneriomyces a new lineage of Dothideomycetes (Ascomycota) basal to Tubeufiales. Phys Chem Chem Phys 176:283-297

Sun Y, Wang Q, Lu X, Okane I, Kakishima M (2012) Endophytic fungal community in stems and leaves of plants from desert areas in China. Mycol Prog 11:781-790

Suryanarayanan TS, Wittlinger SK, Faeth SH (2005) Endophytic fungi associated with cacti in Arizona. Mycol Res 109:635-639

DL (2003) PAUP*: phylogenetic analysis using parsimony (*and other methods), version 4. Sinauer Associates, Sunderland

Tamura K, Stecher G, Peterson D, Filipski A, Kumar S (2013) MEGA6: molecular evolutionary genetics analysis version 6.0. Mol Biol Evol 30:2725-2729

Taylor N, Santos MR, Larocca J, Zappi D (2015) Cactaceae. Lista de Espécies da Flora do Brasil. Jardim Botânico do Rio de Janeiro. http://floradobrasil.jbrj.gov.br/jabot/floradobrasil/FB70. Accessed 3 May 2015

Vidal S, Jaber LR (2015) Entomopathogenic fungi as endophytes: plant-endophyte-herbivore interactions and prospects for use in biological control. Curr Sci 109:46-54

Vilgalys R, Hester M (1990) Rapid identification and mapping of enzymatically amplified ribosomal DNA from several Cryptococcus species. J Bacteriol 172:4238-4246

Wanasinghe DN, Jones EBG, Camporesi E, Boonmee S, Ariyawansa HA, Wijayawardene NN, Mortimer PE, Xu JC, Yang JB, Hyde KD (2014) An exciting novel member of Lentitheciaceae in Italy from Clematis vitalba.

Cryptogam Mycol 35:323-337 
Wanasinghe DN, Jones EBG, Camporesi E, Mortimer PE, Xu J, Bahkali AH, Hyde KD (2015) The genus Murispora. Cryptogam Mycol 36:419-448

Wang Y, Dai C-C (2011) Endophytes: a potencial resource for biosynthesis, biotranformation, and biodegradation. Ann Microbiol 61:207-215

White TJ, Bruns T, Lee J, Taylor J (1990) Amplification and direct sequencing of fungal ribosomal RNA genes for phylogenetics. In: Innis MA, Gelfand DH, Sninsky JJ, White TJ (eds) PCR protocols: a guide to methods and applications. Academic, San Diego, pp 315-322

Wijayawardene NN, Crous PW, Kirk PM, Hawksworth DL, Boonmee S, Braun U, Chomnunti P, Dai DQ, D'souza MJ, Diederich P, Dissanayake A, Doilom M, Hongsanan S, Jones EBG, Groenewald JZ, Jayawardena R, Lawrey JD, Liu JK, Lücking R, Madrid H, Manamgoda DS, Muggia L, Nelsen MP, Phookamsak R, Suetrong S, Tanaka K, Thambugala KM, Wikee S, Zhang Y, Aptroot A, Ariyawansa HA, Bahkali AH, Bhat JD, Gueidan C, De Hoog GS, Knudsen K, McKenzie EHC, Miller AN, Mortimer PE, Wanasinghe DN, Phillips AJL, Raja HA, Slippers B, Shivas RS, Taylor JE, Wang Y, Woudenberg JHC, Piątek M, Cai L, Jaklitsch WM, Hyde KD (2014) Naming and outline of Dothideomycetes-2014 including proposals for the protection or suppression of generic names. Fungal Divers 69:1-55

Woudenberg JHC, Seidl MF, Groenewald JZ, de Vries M, Stielow JB, Thomma BPHJ, Crous PW (2015) Alternaria section Alternaria: Species, formae speciales or pathotypes? Stud Mycol 82:1-21

Zhang Y, Schoch CL, Fournier J, Crous PW, de Gruyter J, Woudenberg JH, Hirayama K, Tanaka K, Pointing SB, Spatafora JW, Hyde KD (2009) Multi-locus phylogeny of Pleosporales: a taxonomic, ecological and evolutionary re-evaluation. Stud Mycol 64:85-102S5 